\title{
A List of the Parasitic Copepoda of Fish obtained at Plymouth.
}

\author{
By
}

P. W. Bassett-Smith, F.Z.S., F.R.M.S., Surgeon, R.N.

THE material from which the present list of Parasitic Copepoda has been compiled was obtained in part by the examination of fish at the Marine Biological Association's Laboratory, but to a still greater extent by daily and diligent search at certain fishmongers' in the town. The following are the most important works consulted :-

1785. Müller, O. F., Entomostraca seu Insecta testacea, Lipsice et Hafnice.

1826 and 1831. Otto and Burmeister, Nova acta Natur Curios.

1832. Nordmann, A. von, Mikrographische Beitrage zur Naturgeschichte der wirbellosen Thiere.

1834-40. Milne Edwards, Histoire Naturelle des Crustacés.

1838. Kroyer, H., Om Snyltelerebsene isaer med Hensyn til den Danske Fauna, Kroyer's Naturhist Tidsskrift, Bd. 2, pp. 7-52, 131-157.

1850. Baird, W., Natural History of the British Entomostraca. Ray Society.

1851. Beneden, P. J. Van, Note sur un Crustacé parasite nouveau, avec l'enumeration des especes, \&c. Bull. de l'Acad. de Belg. tome xviii. 1, pp. 286-290.

1860. Claus, C., Zur Morphologie der Copepoden. Wurzburg naturwiss Zeits. i. pp. 20-36.

1862-68. Hesse, Observations sur des Crustacés rares ou nouveaur des cótes de France. 16 papers, Ann. Sci. Nat.

1865. Heller, C., Crustaceen, Reise der Fregatte Novara.

1866-79. Gerstäcker, A., Crustacea, vol. 5, Bronn. Class. und Ord. des Thierreichs, Copepoda, pp. 590-806.

1875. Claus, C., Ueber die Entwickelung, Organisation und systematische Stellung der Arguliden. Zeits wiss Zool, vol. xxv. pp. $217-224$. 
1875. Claus, C., Neue Beiträge zur kenntniss der parasitischer Copepoden, nebst bemerkungen über das System derselben, tome cit. pp. 327-360.

1877. Kurz, W., Studien über die Familie der Lerncoopodiden. Zeit wiss Zool. vol. xxix. pp. 380-428.

1877. Vogt, C., Recherches Cotières, Arch. Zool. Exper. vol. vi. pp. 385-456.

The system of classification here adopted is that of Gerstæcker, which is founded largely on the minute anatomy of the animals, and is the most recent.

\section{CALIGID}

Caligus, Müller.

Second and third pair of thoracic legs bifid; each branch with two joints, first and fourth not bifid. Fourth pair with elongated basal joint; cephalothorax not deeply notched in the centre, frontal lobe bearing a sucking disc near the base.

a. Abdomen long.

1. Caligus rapax, Milne Edwards. This species was taken in abundance on the surface of the scales of sea trout, Salmo trutta (with Lepeophtheirus stromii), in the mouth of cod, Gadus morrhua, and rarely on the surface of grey mullet, Mugil capito. Male generally found accompanying the female, but in smaller numbers.

2. Caligus diaphanus, Nordmann and Kroyer (not Baird). Found in quantity on the inner surface of the operculum of Trigla hirundo and $T$. cuculus. This species is very small, but agrees exactly with Kroyer's description and plate.

3. Caligus scomberi, n. sp.* I have been unable to place this with any recorded species, and have therefore named it after the fish it is taken from. It is found on the inner surface of the operculum of Scomber scomber. It much resembles the last, but the carapace is oval instead of being rounded, and the abdomen is much longer.

4. Caligus elegans (?), Van Beneden. A doubtful specimen from the mouth of Gadus morrhuce.

5. Caligus (Scicenophillus) tenuis, Van Beneden. Found on the inside of the operculum of Scicena umbra. Four specimens were found, on the only fish of the kind examined, and were unmistakeable.

b. Abdomen short.

6. Caligus minimus, Nordmann. A number of specimens of both sexes were taken from the gill cavity and mouth of the bass, Labrax

* A description, with figures, of this and the other new species mentioned in this paper, at present in manuscript, will be published shortly elsewhere. 
lupus, in June and October. The Hamulus accessorius anterior is particularly long, and the second maxillipedes in the male are very strong and large.

7. Caligus Mülleri, Leach, was found on the surface of the body of poor-cod, but was only seen on a few occasions, a large number of males being taken proportionately to the females. The same Caligus was also found on Trigla gurnardus.

8. Caligus curtus, Müller. This species was taken frequently from the mouth of the cod. Both the description and figure in Müller's work are very indefinite. This species differs from the latter in being rather smaller, the furcula branches longer, and the abdomen rather bigger.

9. Caligus gurnardi, Kroyer. One specimen of this species was taken from the gill cavity of Trigla cuculus in June.

10. Caligus brevipedis, n. sp. ${ }^{*}$ Two specimens of this curious form were taken, in August, from the gill cavity of Motella tricirrata. It differs from all other described species in the rudimentary condition of the fourth pair of thoracic limbs. The same character was found in both specimens, so that it could not well be an abnormality.

\section{Lepeophtheirus, Nordmann.}

Frontal lobes without sucking discs; fourth thoracic segment free; genital segment without lobes on the back; abdomen appearing free behind.

a. Abdomen long.

1. Lepeophtheirus stromii, Baird (vesper of Milne Edwards). Specimens of both sexes of this species were found in quantity on the surface of the body of salmon and salmon-trout in June and July.

2. Lepeophtheirus pollachius, n. sp.* Both sexes taken in quantity from the palate and back of the tongue of Gadus pollachius, also from the gills of the ling, Molva vulgaris. This species is nearly allied to the last mentioned.

3. Lepeophtheirus Thompsoni, Baird. In the gills of turbot and brill, Rhombus maximus and laevis. The specimens of this species were generally found in great numbers in the gills of the above-mentioned fish; I have taken as many as thirty from one. The specimens described by Kroyer as L. rhombus is closely allied in detail, but the carapace as represented by him is very small and round, whereas in this species it is large and distinctly oval, as shown by Baird.

4. Lepeophtheirus obscurus (?), Baird. Found in the gills of Rhombus laevis only. This species has outwardly a very close resemblance to

\footnotetext{
* See former note, p. 156.
} 
the last, but the furcula is distinctly and markedly different, the branches being short, and each branch bifurcating. The male agrees with the description given by Baird of a specimen which I believe he mistook for a female. As this specimen was also taken from the brill, it is likely that they are one and the same species. I have therefore named my specimen accordingly.

b. Abdomen short.

5. Lepeophtheirus pectoralis, Müller. This species was very common, taken all round the year, from plaice, flounder, and dab; very frequently attached to the posterior surface of the pectoral fin, but they were often seen moving actively about over the body of newly-caught fish. Especially common on the flounder. Both sexes abundant.

\section{Elytrophora, Gerstceker.}

(1) All four pair of legs two-branched, the terminal branch of all provided with long plumose hairs. (2) The number of joints in each branch varying. (3) The outer and inner branch of first pair twojointed, both branches of second and third with three joints, the inner branch of fourth with two only.

Elytrophora brachyptera, Gerstacker. From the gills of a large tunny, Thynnus thynnus, taken outside Plymouth, I obtained ten specimens of this species, five of each sex, all alive. These I watched for several hours in a bell-glass. They were very active, and the males were seen to attach themselves to the females in the position represented in Dr. Heller's work, firmly fixed by the hook-like posterior antennæ, and second maxillipedes.

\section{Trebius, Kroyer.}

(1) All four pairs of legs two branched, the terminal joints of all provided with long plumose setae; $(2)$ the outer and inner branch of the first pair with two joints, both branches of second, third, and fourth with three joints.

Trebius caudatus, Kroyer. Specimens were found on the dorsal surface of the head, and in the nasal cavities of the skate, Raja batis, but were not common. One was also taken from the skin of a pollack, but possibly may have found its way there during the manipulation of the fish in the boats or on the quay.

\section{Cecrops, Leach.}

(1) The end joints of the bifid branches of all the true legs, with short hook-like bristles, or having smooth edges; (2) front edge of the cephalothorax deeply cut, two lobed; (3) anterior antennæ covered. 
OF FISH OBTAINED AT PLYMOUTH.

Cecrops Latreillei, Leach. Two specimens were found in the gills of sunfish, Orthagoriscus mola.

PANDARUs, Leach.

(1) Front edge of cephalothorax, not deeply lobed; (2) anterior antennæ free; (3) cephalothorax broader behind than in front; (4) first pair of maxillepeds cheliform; (5) the outer branch of first true leg single-jointed, the inner with two joints, both branches of second and third pairs two jointed, branches of fourth pair one jointed.

Pandarus bicolor, Leach. A number of specimens of this species were taken from the surface of Scyllium catulus.

\section{DICHELESTHINA.}

Lernanthropus, Nordmann.

(1) Abdomen without dorsal plates; (2) the two posterior pair of limbs changed into lamellar appendages; the two first pair very small.

Lernanthropus Kroyeri, Van Beneden. From only one Labrax lupus, in over a dozen examined, did I find any of these curious animals. This was a full-grown fish, and twelve were found, some on the gills of either side. Many of them had the abdomen as a tense bag of bloody fluid, and most had spermatophores attached.

\section{Clavella, Oken.}

(1) Anterior antennæ single, six-jointed, projecting under the edge of the cephalothorax; (2) posterior antennæ with single hook-like claw; (3) only the anterior pair of limbs formed; (4) genital segment of female, five to six times as long as the anterior part of the body.

Clavella mulli, Van Beneden. A number of specimens of this minute species were taken from the gills of the red mullet, all females. The long straw-coloured ovarian tubes are easily seen projecting beyond the gills.

$$
\text { Cycnus, Edwards (Congericola, Van Beneden). }
$$

All four pairs of limbs formed, and two branched anterior antennæ, six-jointed.

Cycnus (Congericola) pallida, Van Beneden. This species was not common. From 14 well-grown conger, I only obtained specimens in two: eleven altogether. They are, however, very difficult to find. The posterior antennæ are very strong and large, compared with the last genus.

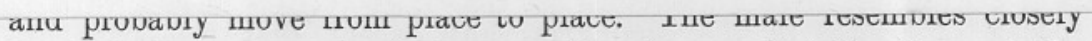
that of $C$. cornutus; in fact, no matter how varied the form of the female in this genus, the males are perfectly distinctive. It was also noticeable that one female would often have more than one male attached, usually to the abdomen. At times as many as five or six would be found fixed on to the various parts of the animal. Occasionally young Caligida were also present as secondary parasites.

\footnotetext{
* See former note, p. 156.
} 


\section{LERN ÆODEA.}

Penella, Oken.

Thoracic legs close together, found just behind the head, neck without distinct segments, egg sacs thread-like, the hinder part of the body (the genital segment) joined to the neck in a straight line; from the end of the latter projects the abdomen, as a long plumose rod. Head rounded and corrugated, carrying behind it two arm-like projections.

Penella sagitta? Linn. One specimen was obtained from the Laboratory, but from what fish was not known.

\section{LeRn fonema, Milne Edwards.}

Genital segment passing gradually into the neck; head obliquely cut off, or rounded in front; genital opening placed far off from it; thoracic legs with developed oar-like joints.

1. Lernconema monillaris, Milne Edwards. A very perfect specimen of this species was found attached to the sclerotic of a young herring taken in November. There was no malformation of the eyeball.

2. Lernceonema encrasicola? Van Beneden. A broken specimen, probably belonging to this species, was taken from a Clupea alosa.

\section{Lernea, Linn.}

Genital segment dilated, bent in the form of an S, and twisted on its axis; head in front bearing slender forked processes; neck short, simple; all four pairs of thoracic legs unfolded.

1. Lernea branchialis, Linnceus. Specimens were taken from the gills of the cod, bass, whiting, haddock.

The body is always full of sanguineous fluid, and the head with its long horns, together with the neck, are deeply buried in the tissues of the gills and head, being surrounded by a laminated clot of blood encysting those parts completely. When once fixed there is apparently no power of movement. The gill cavity of a whiting would appear to be almost filled up with one of these large parasites, and they must materially interfere with the action of the gills.

2. Lernea lusci, n. sp. ${ }^{*}$ This animal was found only in the gills of whiting-pout, Gadus luscus, and was very common, as many as four being found on one fish. The whole head is surrounded by a clot of blood, the elongated horn being buried by the side of the gill bone.

\footnotetext{
* See former note, p. 156.
} 


\section{CHONDRACANTHINA.}

\section{Chondracanthus, De la Roche.}

(1) Cephalothorax not separated from the abdomen by a long thin neck. (2) Front end of the body neither thicker nor more slender than the posterior part. (3) Posterior antennæ in the form of hooks. (4). Cephalothorax without processes. (5) Abdomen compressed with concave sides, or with elongated lobes. Behind the second maxillipedes are two pairs of lobed processes, representing the thoracic limbs.

(a) Two small horns at the posterior angles of the thorax.

1. Chondracanthus cornutus, Müller. A great number of specimens were taken from the gills of the Plaice, $P$. platessa, Flounder, $P$. flesus, and $P$. megastoma. They differed very much in size, being small and especially abundant in the Flounder. The male was almost invariably found fixed on the abdomen of the mature females, by means of its strong, hook-like posterior antennæ.

2. Chondracanthus solece, Kroyer. Found in the gill cavity of Solea vulgaris, but not common; male like the preceding.

3. Chondracanthus clavatus, n. sp.* Found only on the gills of P. microcephalus.

(b) A number of supplementary lobes on the sides, none on the middle line.

4. Chondracanthus triglae, Blainville (C. assellina, Linn). These were plentifully taken from Trigla gurnardus, T. cuculus, and T. hirundo. The whole anterior portion of the head, and so-called neck, is buried in a fleshy mass in the substance of the gill, the thoracic portion only showing.

5. Chondracanthus merluccii, Holten. Taken from the mouth of Gadus merluccius, and is very common; in no fair-sized hake have I ever found it absent. Great numbers are often found together, large areas of mucous membrane being destroyed. The very large hooks of attachment (the second antennæ) being deeply buried, strong muscles are inserted into the bases of these, both for abduction and adduction, so that one would gather that the animal is able to relax its hold, and probably move from place to place. The male resembles closely that of $C$. cornutus; in fact, no matter how varied the form of the female in this genus, the males are perfectly distinctive. It was also noticeable that one female would often have more than one male attached, usually to the abdomen. At times as many as five or six would be found fixed on to the various parts of the animal. Occasionally young Caligida were also present as secondary parasites.

\footnotetext{
* See former note, p. 156.
} 
(c) Supplementary horns in the median line.

6. Chondracanthus Zei, De la Roche (De la rochiana, Blainville). Found on the gills of Zeus faber. This, too, is very common; one of these being usually found on either side in the anterior angle of the gill cavity. When very small, the horn-like processes are soft and crowded. Male like that of $C$. cornutus.

7. Chondracanthus lophii, Johnst. (Ch. gibbosus. Kroyer). Found in almost all well-grown angler fish, Lophius piscatorius, attached to the gills.

\section{LERN EOPODID E.}

\section{LERNAOPODA, Kroyer.}

Cephalothorax short, not attenuated, plainly separated from the body. Maxillipedes of the second pair, long, thin, arm-like, united at their ends; Cephalothorax one-jointed, oval. Body narrow, baglike, only slightly segmented.

1. Lernceopoda salmonea, Linn. ( $L$. carpionis, Kroyer). One female specimen found on the gills of Salmo salar.

2. Lernceopoda galei, Kroyer. Many specimens of this animal were taken from Mustelus vulgaris, Galeus vulgaris, Acanthias vulgaris. They were found attached to the soft skin behind the pectoral and anal fins, more particularly in the deep folds by the anal fins of the male fish, and were frequently taken alive.

\section{Brachiella, Cuvier.}

Cephalothorax markedly thin and elongated, often ringed like a worm. Second maxillipedes are long, arm-like, only united together at their extremity as in the preceding genus, but without articular appendages at their base as in Tracheliastes.

1. Brachiella thynni, Cuv. From one large Tunny, Thynnus thynnus, I obtained four specimens, attached to the soft skin, behind the pectoral fins, two on either side, two being mature and two quite small.

2. Brachiella insidiosa, Heller. These were found attached to the gill rays of the hake, Gadus merluccius, being fairly common. They agree very closely with that described by Heller (obtained from a species of Gadus in the Mediterranean), except that the arms are rather shorter, and the cephalothorax is more acutely bent. Both females and males were found.

3. Brachiella impudica, Nordmann. A number of specimens were taken from different species of Gurnards-Trigla cuculus, T. gurnardus, and $T$. hirundo. They were generally found attached to the soft skin on the inner side of the operculum near to the border, and were very characteristic. The male was generally found fixed 
upon the back of the cephalothorax, and has been described by Milne Edwards.

Var. parva? Very frequently a smaller animal was also found on the same fish, in like positions, apparently differing only in not having any secondary lobular prolongations on the arms. They had the three pairs of horn-like processes posteriorly, and the males appeared identical; but as they bore egg sacs, they might be specifically different.

4. Brachiella bispinosa, Nordmann. Found in quantity from Trigla cuculus, T. gurnardus, T. lyra. Attached to the gill rakers of the outer branchiæ; rarely more than two on each fish. The head has the same characteristic organs as in $B$. impudica. The male, which is found at the back of the cephalothorax, has also equal resemblance.

5. Brachiella triglae (Anchorella trigla, Claus). This species is found attached to the gills of the various Gurnards, T. cuculus, gurnardus, and hirundo, but was not very common. Although in its outward form the female has most of the characteristics of an Anchorella, the male distinctly shows it to belong to this genus.

6. Brachiella merluccit, n. sp.* These animals are always found attached to the points of the gill-rakers of the Hake, Gadus merluccius, and never attached to the gill rays themselves, as B. insidiosa. Both were frequently found in the same fish, but their positions were never other than that noted.

\section{ANChorella, Cuvier.}

Second pair of maxillipedes short, united together, ending close to their origin, in a fixing organ. (Male showing no trace of segmentation of the body, which is not elongated, but globular. B.-S.)

1. Anchorella emarginata, Kroyer. This species was found attached to the gill-rakers of the outer branchiæ of Clupea alosa. The second pair of maxillipedes are not completely united at their base.

2. Anchorella paradoxa, Van Beneden. Found on the gills of Scomber scomber, but rare. The species is, however, very characteristic, and the male is distinctive, but has not yet been described by any author.*

3. Anchorella uncinata, Müller. This species is extremely common, being found in the folds of skin around the mouth, and in the gill-cavity of cod, haddock, pollock, whiting, and whiting-pout. The organ of adhesion of this species is a perfect drill.

4. Anchorella quadrata, n. sp.* A few specimens were obtained of this species from the Dragonet, Callionymus lyra, attached to the gill rakers. This species is much like Anchorella falax, Heller, in form, except for the great size of the abdomen.

\footnotetext{
* See former note, p. 156.
} 